\title{
Phase I / II trial of dose adjusted EPOCH chemotherapy with bortezomib combined with integrase inhibitor therapy for HTLV-1 associated T-cell leukemia lymphoma
}

\author{
Lee Ratner ${ }^{1 *}$, JC Ramos ${ }^{2}$, Ariela Noy ${ }^{3}$, Stefan Barta ${ }^{4}$, Samir Parikh ${ }^{4}$, Adrienne Phillips ${ }^{5}$, Richard Ambinder ${ }^{6}$, \\ Dan Rauch', John Harding ${ }^{1}$, Hicham Baydoun ${ }^{1}$, Xiaogang Cheng ${ }^{1}$, Breanna Caruso ${ }^{7}$, Steven Jacobson ${ }^{7}$
}

From 17th International Conference on Human Retroviruses: HTLV and Related Viruses

Trois llets, Martinique. 18-21 June 2015

Adult T-cell leukemia lymphoma (ATLL) acute and lymphoma subtypes have a poor prognosis, with median survival of about one year. The malignant cells are characterized by high levels of nuclear factor kappa B (NFkappaB). In order to improve therapy, we assessed the safety, tolerance, and efficacy of a combination of dose-adjusted $\mathrm{EPOCH}$ chemotherapy (etoposide, prednisone, vincristine, cyclophosphamide, and doxorubicin), combined with proteasome inhibitor, bortezomib, to prevent degradation of the inhibitor of NFkappaB (IkappaB). In addition, integrase inhibitor, raltegravir, was added to the regimen to block virus replication occurring during treatment. This multicenter study enrolled 18 of 20 planned subjects over $2.5 \mathrm{yrs}$ in the U.S., although 15 of the subjects were born in the Caribbean. Six subjects had acute ATLL, and the remainder lymphoma subtype, all but one with stage 4 disease. Therapy was well tolerated; subjects received 1-6 cycles of therapy (mean 4.5 cycles). Two subjects achieved complete remission lasting for $>12$ mos, 10 subjects had a partial remission, and 3 subjects had stable disease as their best response. Baseline calcium level, absolute lymphocyte count, and proviral DNA load were not predictive of response. Correlations with proviral expression, integration site, and integrase gene analyses will be presented. Supported by NIH grants CA94056, CA1730, CA63413, Lymphoma Leukemia Society grant 6067-10, and Lymphoma Research Foundation grant 307181203.

* Correspondence: Iratner@dom.wustl.edu

'Division of Oncology, Washington University, St Louis, MO, USA

Full list of author information is available at the end of the article

\section{Authors' details}

${ }^{1}$ Division of Oncology, Washington University, St Louis, MO, USA. ${ }^{2}$ University of Miami, Miami, FL, USA. ${ }^{3}$ Lymphoma \& Hematology Division, Memorial Sloan Kettering Cancer Center, New York, NY, USA. ${ }^{4}$ Divisions of Hematology-Oncology, Montefiore Hospital, New York, NY, USA. ${ }^{5}$ Columbia University, New York, NY, USA. ${ }^{6}$ Division of Hematologic Malignancies, Johns Hopkins University, Baltimore, MD, USA. ${ }^{7}$ NINDS, NIH, Bethesda, MD, USA.

Published: 28 August 2015

\section{doi:10.1186/1742-4690-12-S1-P21}

Cite this article as: Ratner et al:: Phase I / II trial of dose adjusted EPOCH chemotherapy with bortezomib combined with integrase inhibitor therapy for HTLV-1 associated T-cell leukemia lymphoma. Retrovirology 2015 12(Suppl 1):P21.
Submit your next manuscript to BioMed Central and take full advantage of:

- Convenient online submission

- Thorough peer review

- No space constraints or color figure charges

- Immediate publication on acceptance

- Inclusion in PubMed, CAS, Scopus and Google Scholar

- Research which is freely available for redistribution
() Biomed Central 